Annales de Parasitologie (Paris), t. 45, 1970, $\mathrm{n}^{\circ}$ 6, pp. 805 à 813

\title{
Pathological and biochemical changes in rats infected concurrently with Nippostrongylus brasiliensis and Trypanosoma congolense
}

\author{
by J. O. SIMAREN and F. M. BAMMEKE \\ Laboratory of Parasitic Diseases and Biochemistry, Department of Biological Sciences, \\ University of Ife, Ile-Ife, Nigeria
}

\section{Résumé}

Tous les rats ont reçu la dose-étalon, soit de $1.000 \mathrm{~N}$. brasiliensis, soit de 10.000 trypanosomes, soit les deux. Il résulte de l'infection simultanée que les trypanosomes qui apparaissent sont bien moins nombreux que ceux qui apparaissent lors de l'infection unique. On a vu une quantité progressivement croissante de trypanosomes se manifester beaucoup plus dans les infections doubles que dans les infections uniques.

Le taux de glucose est plus haut dans les infections à Nippostrongylus que dans les infections des autres groupes. Les résultats montrent que les infections à $T$. congolense et à $N$. brasiliensis changent le métabolisme des hydrates de carbone du rat. Sauf pour les infections à Nippostrongylus dans lesquelles on a vu une augmentation du taux de l'albumine, les globulines alpha et béta ne se modifient pas beaucoup pendant la même période, alors que l'albumine diminue.

\section{Summary}

All the rats received the standard dose of either 1,000 infective $N$. brasiliensis or 10,000 trypanosomes or both. In the concurrent infection the total number of trypanosomes produced was considerably lower than in the single infection. A gradual rise in trypanosome population was more observed until necropsy in double infections than in single infections. 
The amount of glucose in Nippostrongylus infections was higher than in other infected groups. The result shows that there is an alteration in the carbohydrate metabolism of the rats by both $T$. congolense and $N$. brasiliensis infections. Albumin decreased and alpha and betaglobulins did not differ much in the same period except in the Nippostrongylus infections where albumin increased.

\section{Introduction.}

Of recent, the techniques of studying parasitic infections in man and animals in elucidation of host parasite relationship have now shifted to includ immunological, biochemical, cellular and microbio'ogic alterations of the host to the parasite. Sokolic et al 1963, observed acquired immunity in sheep infected with Dictyocaulus filaria. Cox 1964 reported immune response to Trypanosoma cruzi and T. lewisi infection in rat and mice. Herlich and Merkel (1963) observed a relative increase in gammaglobulin in calves infected with Trichostrongylus axei. Sadun et al 1965 reported significant differences in glucose leve's in mice infected with spargana of Spirometra mansonoides than in the uninfected controls.

Larsh and Donaldson (1944) demonstrated that mice infected concurrently with Nippostrongylus muris and Hymenolepis nana exhibited a marked immunity to the tapeworm by harbouring one-half of the number of cysticercoids observed in the controls. Simaren $(1969,1970)$ observed some cellular and striking pathological changes in rats infected with $N$. brasiliensis and $T$. brucei with particular references to their growth and development. He attributed these changes, reduced egg production, stunting and loss of the adult parasitic nematode to physiological factors associated with the beginning of an acquired immunity of the host to the infection. The purpose of this investigation therefore is to find out further, biochemical and qualitative cellular changes occuring in rats infected concurrently with Trypanosoma congolense and Nippostrongylus brasiliensis.

\section{Materials and Methods.}

Three groups 10-12 weeks old white laboratory bred rats (6 per group) were selected for infection. The strain of $N$. brasiliensis and the trypanosome species used were being maintained in our parasitology laboratory for the past 3 years. Procedures for the maintenance of these test agents are similar to those described by Haley 1966a, Yogogawa 1922, Lincicome and Watkins 1963. Group I was infected with $T$. congolense alone. Group II was concurrently infected with $T$. congolense and $N$. brasiliensis. Group III received $N$. brasiliensis only while group IV was the uninfected control. Each rat received either 1,000 Nippostrongylus larvae or 10,000 Trypanosomes or both. All infected rats were individually kept in clean cages and were fed with commercial food pellets and water. Quantitative standardization of the try- 
panosomes count was accomplished by determining the trypanosomes in $1 \mathrm{ml}$ of blood suspension by use of hemocytometer and blood pipettes. The white blood cells and the red blood cells were counted using appropriate blood pipette and mixture of diluting fluid $(0.75 \mathrm{ml}$. of $1 \%$ Saponin in normal $\mathrm{NaCl} ; 0.5 \mathrm{ml}$. of $1 \%$ Toluidine Blue in normal $\mathrm{NaCl} ; 4 \mathrm{ml}$. of $10 \%$ Formalin, in normal $\mathrm{NaCl}$; and $4.75 \mathrm{ml}$. of $1 \%$ sodium citrate) for Trypanosome count. A solution of $16.5 \mathrm{ml}$. of acetic acid glacial, $6.25 \mathrm{gm}$. sodium sulphate crystal both in $100 \mathrm{ml}$. distilled water was used for red blood cell count; and $2 \mathrm{ml}$. acetic acid glacial in $98 \mathrm{ml}$. distilled water with two drops of Methyl violet 6 B for white blood cell count (Stiff, Clough and Branham, 1948). The degree of trypanosome parasitemia was checked daily.

Blood collected by cardiac puncture from infected rats in each group were chemically analysed. Glucose level determination was by Folin and Wu method (1920). The protein free blood fitrate were heated with alkaline copper solution using special tube to prevent reoxidation. The cupprous oxide formed was treated with a phosphomolybdic acid solution to produce blue molybdenum oxide whose concentration was directly proportional to the amount of glucose present. The glucose amount was estimated with a spectrophotometer at $420 \mathrm{mu}$. A modified method of paper électrophoresis (Chen 1959) using a Shandon type of electrophoresis cell was carried out on three serum samples $(20 \mathrm{ml}$. each) from each group experiment. Separate strips of Whatman paper No. $3 \mathrm{MM}(28 \times 5 \mathrm{~cm})$ previously moistened with phthalate buffer ( $\mathrm{pH}$ 5.6) were spotted and a current of $17.5 \mathrm{mM}$ on 150 volts was applied to the strips and ran for $3 \mathrm{hrs}$. The strips were then stained with 0.1 Bromophenol blue in absolute methanol, containing $6 \% \mathrm{HgCl}_{2}$ washed in running water and dried at room temperature. Quantitative determination of each protein fraction was individually eluted in $5 \mathrm{ml}$. $50 \%$ alkaline methanol. The colour intensity of the eluate was spectophotometrically estimated at $595 \mathrm{mu}$. Daily body temperatures of all rat were rectally taken and recorded.

\section{Results and Discussion.}

In the four groups of experiments performed, the course of infection and individually traced degree of parasitemia was interpreted by means of trypanosome count, white and red blood cell count, changes in body temperature, glucose and protein levels of the infected rats sera.

From the data collected the prepatent period for $N$. brasiliensis was normal. The daily average number of trypanosomes per $\mathrm{mm}^{3}$ was significantly higher, 289,600 in single infection and 198,000 in the conzurrent infection on the 9 th day post infection (Tables I et II).

Daily qualitative rate of trypanosomes developments was slower in concurrent than sing'e infections with the former attaining a peak on the 11 th day. Higher body temperatures were recorded for consecutive three days preceeding death in the double infections than in the single infections. 

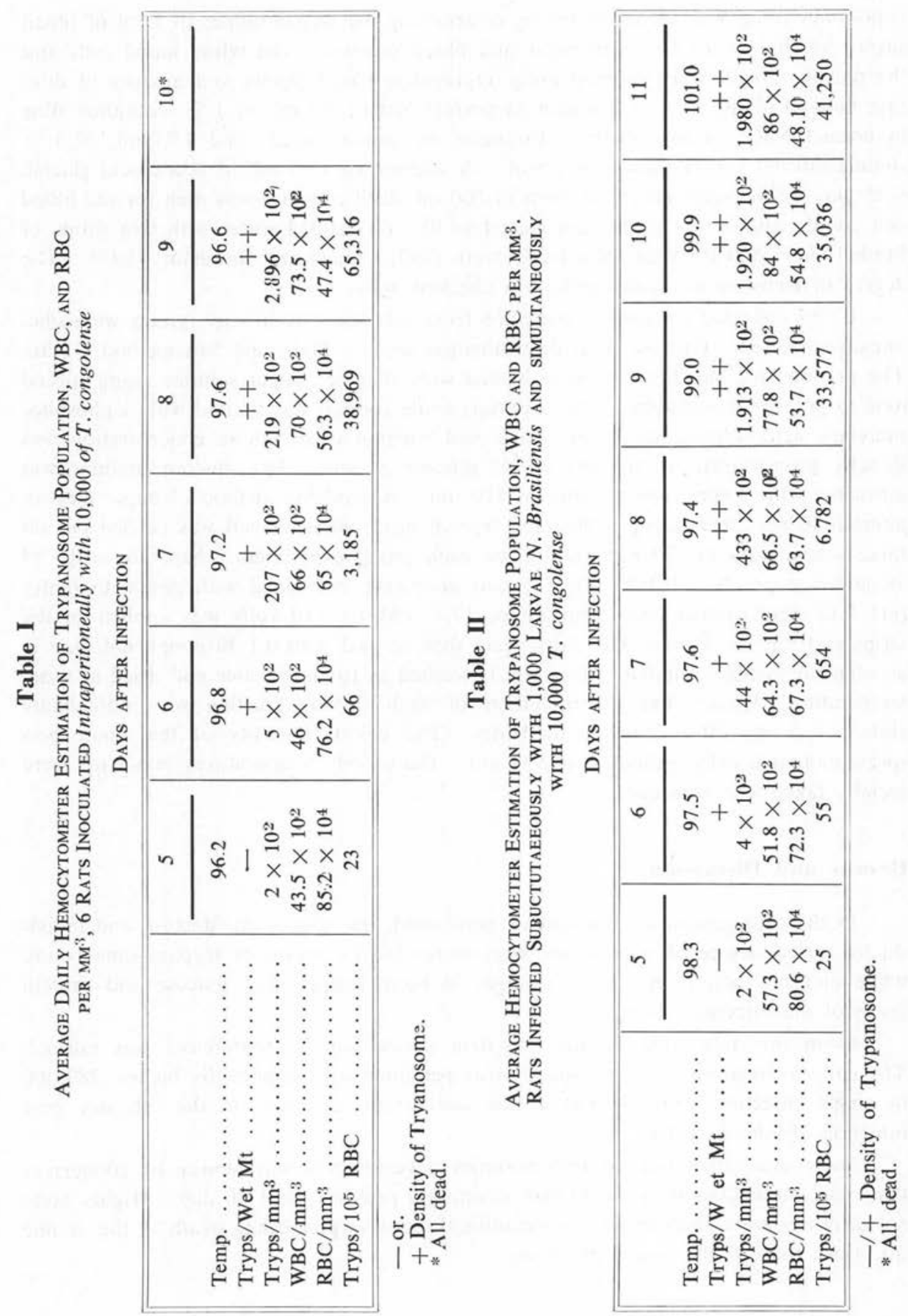

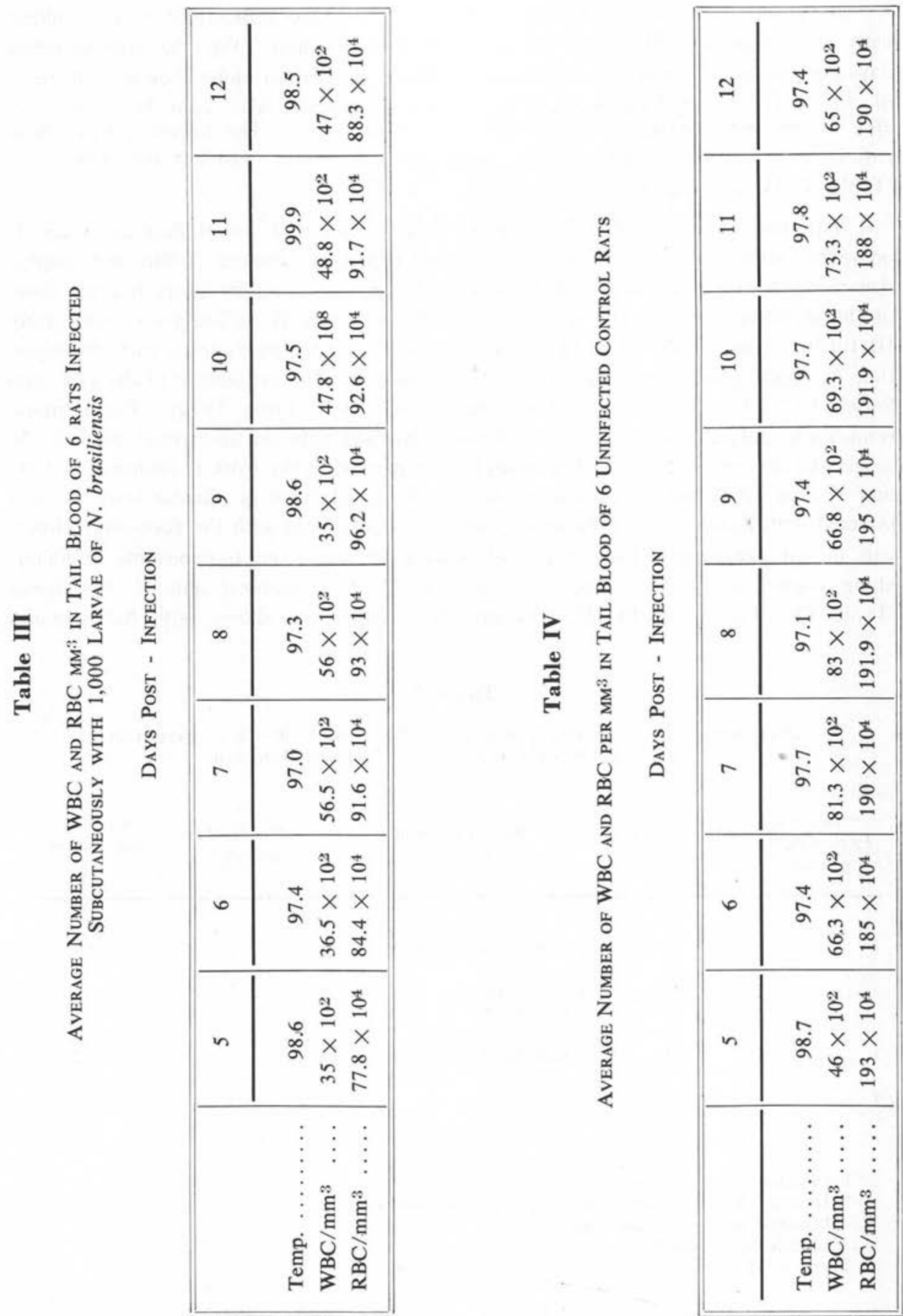
In group IV (uninfected control) the daily average $\mathrm{RBC} / \mathrm{mm}^{3}$ was stabilized with an average of $856 \times 10^{4}$ for days 5-9 post infection. For the corresponding days post infection, group III rats infected with $N$. brasiliensis alone showed a decrease of $443 \times 10^{4} \times 10^{4} \mathrm{RBC} / \mathrm{mm}^{3}$, while group II infected with both $N$. brasiliensis and $T$. congolense gave a lower $337,6 \times 10^{4} \mathrm{RBC} / \mathrm{mm}^{3}$. The lowest average indicated by group I infected with $T$. congolense alone was $330.3 \times 10^{4} \mathrm{RBC} / \mathrm{mm}^{3}$ (Tables I - IV and Fig. 1).

The destrution of RBC is more pronounced in group I and II than in group III compared with group IV. These confirm the report of Simaren (1970) and emphasise more quantitatively the pathobiological changes occuring by using heavier doses of the infective agents. The decrease in RBC in groupe II as compared with group III further indicates the effect of parasitemia of $T$. congo!ense coupled with the ingestion of blood and destruction of intestinal tissue by $N$. brasiliensis (Taliaferro and Sarles 1939, Porter 1935b, and Simaren 1964, 1967, 1969, 1970). Furthermore, remarkable differences in glucose level were observed between uninfected control, the single and double infections. The result here is parallel to the work of Sadun et al 1965 and Symon 1960c who reported similar significant changes in glucose level in mice infected with Spargana of Spirometra masonoides compared with the controls. However, in our experiments the amount of glucose in sera from trypanosome infections alone showed a much absorbance of glucose by $T$. congolense and $N$. brasiliensis (Table V). Traces of the different protein fractions are shown with beta-globulin

\section{Table V}

Date Showing the Average Amount of Glucose in Blood of Infected - and 6 Uninfected rats at the Peak of Infection

\begin{tabular}{|c|c|c|c|c|c|}
\hline $\begin{array}{l}\text { * No. to } \\
\text { Experiment } \\
\text { groups }\end{array}$ & $\begin{array}{l}\text { Days after } \\
\text { infection }\end{array}$ & $\begin{array}{c}\text { No. of Parasites } \\
\text { per Rat }\end{array}$ & & $\begin{array}{l}\text { No. of Rats } \\
\text { necropsied }\end{array}$ & $\begin{array}{l}\text { Glucose } \\
\mathrm{mg} / 100 \mathrm{ml} \text {. } \\
\text { bld. }\end{array}$ \\
\hline $1 \ldots \ldots \ldots$ & 8 & $10,000 \mathrm{~T}$. congolense & & 3 & 8 \\
\hline $2 \ldots \ldots \ldots$ & 9 & $\begin{array}{c}10,000 \text { Tryps }+ \\
1,000 \text { Nippo }\end{array}$ & & 3 & 1.5 \\
\hline $3 \ldots \ldots \ldots$ & 10 & $1,000 \mathrm{~N}$. brasiliensis & & 3 & 27.5 \\
\hline $4 \ldots \ldots \ldots$ & 10 & & & 3 & 36 \\
\hline
\end{tabular}

* 1 Infected with $T$. congolense alone.

2 Infected with $T$. congolense and $N$. brasiliensis.

3 Infected with $N$. brasiliensis alone.

4 Uninfected control.

Tryps $-T$, congolense; Nippo $-N$. brasiliensis, 


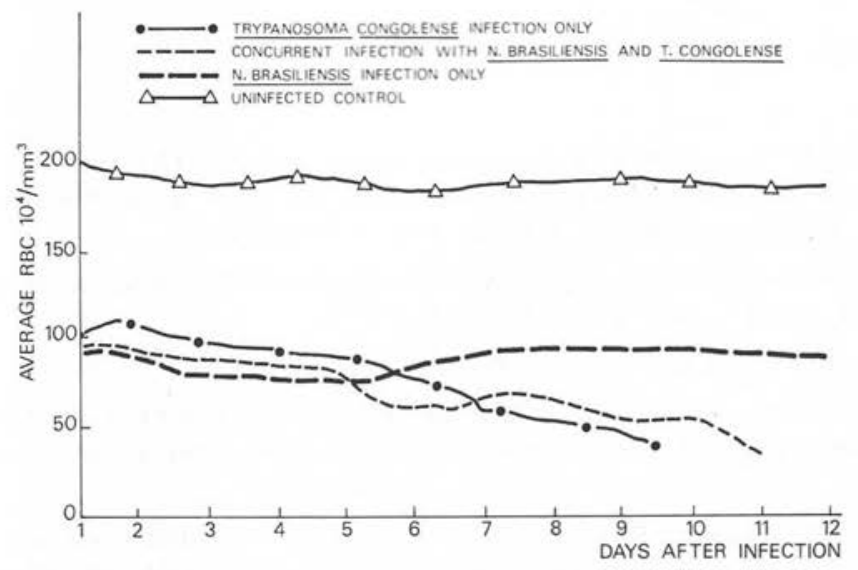

FIG. 1. - Comparative average $\mathrm{RBC} / \mathrm{mm}^{3}$ in rats infected concurrently with $T$. congolense and $N$. Brasiliensis singly with both $T$. congolense and $N$. Brasiliensis, and in the uninfected control

absent in group III infected rats, while post-albumin fraction were absent in groupe I and II infections (Table VI). This depressed protein digestion in rats infected with $N$. brasiliensis was likewise observed by Symons (1960d) Kagan et al (1961). The degree of parasitemia found to be higher in single infections than in the concurrent infections is probably due to the competition for food nutrients between the parasites in the concurrent infections.

ACKNOWLEDGMENT: Our appreciation is expressed to University of Ife for the research grant with has aided this study. Thanks also to Dr. R. A. Balogun for his cooperation on the proetin analysis.

\section{Table VI}

Data Showing the Extinction Values of Protein Fractions from Sera of Infected AND UNINFECTED RATS

\begin{tabular}{|c|c|c|c|c|c|}
\hline \multirow{2}{*}{$\begin{array}{l}\text { * No. to Ex- } \\
\text { periment } \\
\text { group }\end{array}$} & \multirow{2}{*}{$\begin{array}{l}\text { No. of rats } \\
\text { necropsied }\end{array}$} & \multicolumn{4}{|c|}{ Mean Absorbance } \\
\hline & & Albumin & Post-Albumin & $\alpha$-globulin & $\beta$-globulin \\
\hline $1 \ldots \ldots \ldots$ & 3 & .66 & - & .192 & .11 \\
\hline $2 \ldots \ldots \ldots$ & 3 & .56 & - & .18 & .155 \\
\hline $3 \ldots \ldots$ & 3 & 1.38 & .182 & .16 & - \\
\hline $4 \ldots \ldots \ldots$ & 3 & .99 & .08 & .156 & .28 \\
\hline
\end{tabular}

* As in Table V. 


\section{References}

Chen (D. L.), 1959. - Studies on the protein metabolism of Culex pipiens L. III. A comparative analysis of the protein contents in the larval Haemolymph of Autogenous and Anautogenous forms. J. Insect. Phy. 3: 335-344.

Cox (H. W.), 1964. - Immune response of rats and mice to Trypanosome Infection. J. Parasitol., 50 (1): 15-22.

Folin et Wu, 1920. - J. Biol. Chem., $41: 367$.

Haley (A.-J.), 1966 a. - Biology of the rat nematode Nipponstrongylus brasiliensis (Travassos, 1914). III. Characteristics of $N$. brasiliensis after 30 to 120 serial passages in the Syrian hamster. J. Parasitol., 52: 98-108.

HeRlich (H.) et Merkel (R.S.), 1963. - Serological and Immunological responses of calves to infection with Trichostrongylus axei. J. Parasitol., 49: 623-627.

KaGAN (I. G.) et Goodchild (C. G.), 1961. - Paper electrophoresis of sera from man and experimental animals infected with various helminths. J. Parasitol., 47: 373-377.

LINCICOME (D. R.) et WATKINS (R.C.), 1963. - Method for preparing pure cell suspensions of Trypanosoma lwewisi. Am. Inst. Biol. Sci. Bull., 13 (4) : 53-54.

Porter (D. A), 1935 b. - A comparative study of Nippostrongylus muris in rats and mice. Am. J. Hyg. $22: 444-466$.

Sadun (E. H.) et Williams (J. S.), Meroney (F. C.) et Mueller (J. F.), 1965. - Biochemical changes in mice infected with Spargana of the Cestode Spirometra mansonoides. J. Parasitol., 51 : 532-536.

Simaren (J. O.), 1964. - Quantitative studies on Development of Nipponstrongylus brasiliensis after Different Routes of Infection. Proc. Helm. Soc. Wash., 31 (2) : 281-284.

—, et FabianeK (J.), 1967. - Factors Affecting Survival and Development of Nipponstrongylus brasiliensis in Infected rat. The Physiol., 10 (3) : 306.

-, 1969. - Quantitative Investigation of Nipponstrongylus brasiliensis. Acting as Vector of Trypanosoma congolense or Trypanosoma brucei in rats. Ann. de Parasitol., 44 (5) : 531-537.

-, 1970. - Biological observation in quantitative tests of Nipponstrongylus brasiliensis Acting as Vector of Trypanosoma brucei or Trypanosoma congolense. Experientia, $26(5): 555-556$.

Sokolic (A.), Jovanoic (M.), Cuperlovic (K.) et Muvsesijan (M.), 1963. - Inhibition of development of Dictyocaulus filaria as an expression of Immunity attained in sheep. J. Parasitol., 49: 612-616.

Stiff (E. R.), Clough (P. W.) et Branham (S. E.), 1948. - Practical Bacteriology Hematology and Parasitology. The Blakiston Comp. N. Y. 10th, Ed. 377-414.

SYMON (L. E. A.), 1960 c. - Pathology of Infestation of the rat with Nipponstrongylus muris (Yokogawa). IV. The absorption of glucose and Histidine. Austral. J. Biol. Sci., 13: 171-179. 
-, 1960 d. - Pathology of infestation of the rat with Nipponstrongylus muris (Yokogawa). V: Protein digestion. Austral. J. Biol. Sci., 13: 578-583.

Taliaferro (W. H.) et Sarles (M. P.), 1939. - The Cellular reactions in the skin, lungs and intestines of normal and immuned rats after infection with Nipponstrongylus muris. J. Inf. Dis., 64 : 157-192.

Yokogawa (S.), 1922. - The development of Heligmosomum muris, a nematode from intestine of wild rat. J. Parasitol., 14: 127-166. 